\title{
Study of the Effectiveness of Girls' Stipend Program in Public Schools -Sindh
}

\author{
Muhammad Safar Unar ${ }^{1}$ \\ Prof. Dr. Tayyaba Zarif ${ }^{2}$
}

\begin{abstract}
Women empowerment through education process is the key element for the national development by providing basic resources \& facilities. Every country has made systemic initiatives for the development of girls' education at all levels. Pakistan has also started many motivational steps for girls education especially government of Sindh has taken many initiatives to promote girls education. In this connection, girls' stipend program was started in 2001 for girls studying at VI to X level in public schools of Sindh. The primary purpose of this study was to know effectiveness of girls' stipend program in public schools of Sindh on the enrollment, attendance of girls, encouragement of parents' motivation \& interest level of parents' towards continuity of education process as per the perception of head teachers. The study was descriptive in nature and quantitative by method. Population of this study was all head teachers of elementary, middle and secondary schools of Sindh. Targeted population of this study was all head teachers of elementary, middle and secondary schools of district Shaheed Benazir Abad. Seventy percent head teachers of elementary, middle and secondary schools were selected by convenient random sampling from the targeted population of the study. Questionnaire with five points Likert scale was developed for exploring the perception of head teachers' about effectiveness of girls' stipend program. Data were analyzed with the help of percentages. Findings of this study identified that girls' stipend program proved as motivational factor for the enrolment, attendance, continuity and encouragement of parents and for girls who were studying in $6^{\text {th }}$ to $10^{\text {th }}$ classes in public schools.
\end{abstract}

Keywords: Effectiveness, Girls' Stipend Program, Education process, Perception, Head teachers

\section{Introduction}

The education is key factor for a successful nation and all the progress, development and sustainability depend upon quality of education. Education

\footnotetext{
${ }^{1}$ Research Associate, Shaheed Benazir Bhutto University, Shaheed Benazir Abad, Sindh

${ }^{2}$ Chairperson, Department of Education, Shaheed Benazir Bhutto University, Shaheed Benazir Abad, Sindh

Email: dr.tayyabazarif@gmail.com
} 
enhances the status of human being and guides everyone to prosperity and liberty, because of that our great leader and founder of Pakistan Quaid-e-Azam Muhammad Ali Jinnah laid stress on getting education. Once, he said to the students in his speech that "Education is a matter of life and death for our country" and Robert Hutchins said about education as "The object of education is to prepare the young to educate themselves throughout their lives" and on another place Edward Everett describes that "Education is a better safeguard of liberty than a standing army". Education turns huge population into productive human resource.

Education is the initial element for everyone, male as well as female equally. Every Pakistani citizen has right to get education according the constitution of Pakistan, as the article 25-A constitution of Pakistan states that "The state shall provide free and compulsory education to all children of the age five to sixteen years in such a manner as may be determined by the law" and before the $18^{\text {th }}$ amendment of constitution, Pakistan's education system was the responsibility of federal government and ministry of education at federal level was the responsible for the planning, formulating policies and promotion of educational facilities in the country, but after the $18^{\text {th }}$ amendment the responsibilities of education system were divided among provinces and federation level. As, 52\% of the total population of Pakistan consist on female gender. So it is very important to educate female to make nation stable, developed and successful country in the world. Government of Pakistan is facing the problem of low rate of girls' education since many years. Mostly in all developing countries, secondary school enrolment lowers for female than male, especially in remote areas (Khandker, 2003).

Main center of literacy programmes in Pakistan was on the girls' population. More than $80 \%$ of literacy centers were for female. A number of improvement programs and project have been launched since 2000 for the encouragement of girls' primary education and female literacy. These projects and program were starting to show optimistic consequences. (Government of Pakistan, 2008) In every province, girls' education remained big challenge, and so many initiatives were being taken by province such as free text book, free and quality education for remote areas by the collaboration of Sindh education foundation, and girls' stipend program in all public school of Sindh.

As Pakistan consists of four provinces namely Sindh, Punjab, Baluchistan and Khyber Pakhutun khuwah (Government of Pakistan, 2008), every province is trying to improve its educational ratio, for that Government of Sindh has initiated many positive steps to improve the educational ratio in both rural and urban areas. Sindh government also started many reforms programs to enhance the 
enrollment, such as free text book, free education for all at door step by private partnership with the collaboration of Sindh Education Foundation scholarships in higher education and stipend program for female students in all public schools. Government of Sindh has started education reform program to deal the issues of quality, governance and access of education. Girls' stipend program is the one part of this program. Girls' stipend program introduced from 2001 due to low enrolment in classes from VI to $\mathrm{X}$ in all public schools of Sindh government ("Sindh Education Foundation", 2018)

Sindh government started girls' stipend program from 2001-2002 academic years as motivational factor to enhance enrollment and reduce the drop out ratio in secondary education and still it is supporting to all those girls who are studying in class $6^{\text {th }}$ to $10^{\text {th }}$ in public schools of Sindh. Many researchers conducted researches related to the girls stipend program in Pakistan and in the world, but in Sindh province of Pakistan, particularly in district Shaheed Benazir Abad, there was no any research conducted about girls' stipend program, according to the researchers' knowledge, so that researcher decided to conduct a research about the effectiveness of girls' stipend program in Sindh. The rational of this study was to explore the effectiveness of girls' stipend program, according the perception of Head teachers in all elementary, middle and secondary girls and mixed public schools of Sindh.

\subsection{Objectives of Study}

1. To analyze the perception of Head teachers about effectiveness of Girls stipend program regarding the enrollment of girls students in public schools.

2. To assess the attendance of girls' students in classes $6^{\text {th }}, 7^{\text {th }}, 8^{\text {th }}, 9^{\text {th }}$ and $10^{\text {th }}$ after starting Girls stipend program.

3. To find out interest level of girls students due to Girls stipend program.

4. To assess the encouragement level of parents of girls student due to Girls stipend program

5. To evaluate the motivational level of girls and their parents due to Girls stipend program

6. To evaluate the continuity of girls students from $6^{\text {th }}, 7^{\text {th }}, 8^{\text {th }}, 9^{\text {th }}$ and $10^{\text {th }}$ classes In public schools due to Girls stipend program

\subsection{Research Questions}

1. Do the Head teachers percept about effectiveness of Girls stipend program regarding enrollment of girls' students in public schools?

2. Do Head teachers satisfy with the attendance of girls students in classes $6^{\text {th }}$ to $10^{\text {th }}$ due to girls' stipend program? 
3. Do the head teachers agree with the interest level of girls students increased due to the girls' stipend program?

4. Do the head teachers' percept that encouragement of parents of girls students enhanced due to girls stipend program?

5. Do the Head teachers percept that motivational level of girls and their parents enhanced due to girls stipend program?

6. Do the head teachers satisfy on the continuity of girls' education in classes $6^{\text {th }}, 7^{\text {th }}, 8^{\text {th }}, 9^{\text {th }}$ and $10^{\text {th }}$ due to the girls' stipend program?

\subsection{Scope of the Research}

The main object of this study was to explore the effectiveness of girls' stipend program in public schools of Sindh, according the perception of head teachers. Researcher focused perception of head teachers to explore the effectiveness of girls stipend program of girls and mixed elementary, middle and secondary public schools of district Shaheed Benazir Abad, on the:

a) Enrollment enhancement

b) Attendance of girls' students

c) Encouragement of parents

d) Motivational level of girls and their parents

e) Interest level of girls' students

f) Continuity in education

\subsection{Signification of Study}

The findings of this study will provide deep perception of Head teachers of elementary, middle and secondary publics' schools of Sindh. This study will be helpful for Sindh government, education department, Reform Support Unit (RSU) and other stake holders, who are working for the betterment of girls' education and enhancement of enrollment of girls' students. This study will also help the stakeholders, policy makers, education department and government of Sindh to guide them to make effective strategies to enhance the enrollment of female students in public schools of Sindh.

\subsection{Limitation of Study}

Girls stipend program started 2001-2 in public schools of Sindh, As girls' stipend program is for all those girls' students who are studying in classes VI to $\mathrm{X}$ in the public schools of government of Sindh, however due to the limited time and sources, this research is delimited to the perception of headmasters/ headmistress regarding the effectiveness of girls' stipend program of elementary, middle and secondary schools of district Shaheed Benazir Abad, division Shaheed Benazir Abad province Sindh. 


\section{Review of Literature}

One of the first attempts in the field of education and literacy was the National Education Conference in 1947. The Quaid-e-Azam, in his message to the Conferences said:"... The importance of education and the type of education cannot be over-emphasized ... There is no doubt that the future of our State will and must greatly depend upon the type of education we give to our children, and the way in which we bring them up as future citizens of Pakistan ... We should not forget that we have to compete with the world which is moving very fast in this direction." (Government of Pakistan, 1947).

At the Rio conference, which was held in 2012 in Brazil, the United Nations announced that the education gap to be a main difference urbanized and developing countries' World Bank (2005) has recognized the government's education policy to be broad but very motivated and in front of the capability of the Ministry of Education. UNICEF works with the Pakistan Government to support the education sector at all levels. This includes providing technical support such as research, planning, monitoring and policy formulation, particularly to establish alternative education pathways for the most marginalized children (Government of Pakistan, 2008).

Sperling and Barbara (2004) stated that, according the World Bank a study of hundred countries described that rising the share of female who have a secondary education by 1 per cent boosts once a year for every capita income with 0.3 per cent. According to Herz (1991) Girls' education may bear from the higher expenses of educating girls than boys in many developing countries. Dollar and Gatti (1999) discover that female education, particularly at the secondary level, is the cause of economic increase. In favor of Tajikistan, the World Bank (2005) has recognized gender equity and equality as a critical trouble, but has argued for attempt common education issues, failing to intend policies particularly expected at reducing the gap in girls' education; it cites the small quantity of funds as a main restraint. Amartya Sen, as the economist expert observes, that "The changing agency of women is one of the major mediators of economic and social change...Nothing, arguably, is as important today in the political economy of development as an adequate recognition of political, economic and social participation and leadership of women" (Sen, 2000).

An investigation with both house circle- and school-level data shows that the national rural stipend program for girls has had an important encouraging impact and fruitful factor on the secondary school in Bangladesh (Khandker, Pitt \& Fuwa, 2003). This positive development has occurred due to some specific public interventions focusing on girl students, such as stipends and exemption of tuition fees for girls in rural areas, and the stipend scheme for girls at the secondary 
level. Bangladesh has made significant progress in promoting the objectives of ensuring gender equality and empowerment of women (United Nations, 2012)

Educating girls and young women is an important development objective, reflected, for example, in the United Nations Millennium Development Goals. Motivated by the potential long-term benefits of improving education levels, a number of developing countries have abolished school tuition fees, experimented with compulsory education laws and/or introduced stipend programs designed to increase educational attainment, particularly for girls (Hahn, Islam, Patacchini \& Zenou, 2015). Many researchers conducted researches on the stipend program in Pakistan, Bangladesh and in many other countries of the world but in Sindh particularly in district Shaheed Benazir Abad no any research conducted on the stipend program, so it will be first research on the effectiveness of stipend program in Sindh.

Sindh government took many steps for the betterment of students especially for girls, for example, free text books from class I to X all government schools of Sindh, free education for all (PPRS, IELP) in rural areas, where no government school exists, Scholarships in higher education and stipend program for girls students, who are studying in class VI to X in elementary, middle and secondary public schools in government of Sindh. As girls' education remained main issue especially in Sindh, so government of Sindh planned to start stipend program to enhance the enrollment of girls' students in class VI to X in Elementary, middle and secondary public schools. This program had been started in 2001 and still it is continue. So the researcher highlighted the status of stipend program and its effect on girls' enrollment, attendance, interest level and encouragement level of their parents.

\subsection{Research Design}

\section{Research Methodology}

The research design of this study was quantitative by method and descriptive by purpose. Researcher tried to explore the perception of Head teacher on: Enrollment of girls' students, Attendance of girls' students, and Interest level of girls' students, Encouragement of parents, Motivational level of girls' students and parents and Continuity of girls' education from classes VI to X.

\subsection{Population and Sample}

As the population of this study was all Head teachers of Government girls and mix secondary, middle and elementary schools of Sindh, in which girls students of class $6^{\text {th }}, 7^{\text {th }}, 8^{\text {th }}, 9^{\text {th }}$ and $10^{\text {th }}$ were getting education, In S.B.A district numbers of schools were 69, 55 and 48 secondary, middle and elementary respectively. District Shaheed Benazir Abad had four talukas namely: 
Nawabshah, Sakrand, Kazi Ahmed and dour. Researcher selected $80 \%$ of the total girls and mixed elementary, middle and secondary schools of district Shaheed Benazir Abad through non probability (convenient) sampling technique.

According to (Sindh Education Foundation) the quantity of girls and mixed secondary, middle and elementary schools were 1153, 1437 and 415 respectively in Sindh and targeted population was district Shaheed Benazir Abad, so girls and mixed secondary, middle and elementary schools were 69,55 and 44 respectively in (S.B.A) and targeted sample was $80 \%$ of targeted population which were 55 , 48 and 38 girls and mixed secondary middle elementary schools respectively of S.B. Abad ("School Education and Literacy Department", 2018).

\subsection{Instrumentation}

The researcher used closed ended questionnaire for the respondents (which were Head teachers), which was consist on five point Likert scale including agree, strongly agree, undecided, disagree and strongly disagree. Research tool was developed by the help of literature review and existing material of girls' stipend program on the RSU website ("RSU", 2018). The tool was discussed with senior head teacher of public schools and research supervisor and got valuable feedback and guidance for improvement of research tool, and detailed discussion was arranged with consultant/coordinator of LSU (Local Support Unit) district Shaheed Benazir Abad regarding suggestion and guidance for the tool improvement. In last, with the help of valuable feedback of supervisor, discussion with head teachers and valuable suggestions of consultant of LSU, research tool was modified and finalized for data collection. 5\% piloting study was conducted from targeted population, on the basis of piloting researcher made some changes and modified some items.

\subsection{Data Collection}

For data collection researcher personally visited targeted population and researcher met with head teachers and distributed close ended questionnaire as research tool among them.

\subsection{Data Analysis}

Collected data were analyzed with the help of MS excel and MS word in the form of tables and percentages. 


\section{Data Analysis}

Table 4.1 Perceptions of head teachers about effectiveness of girls' stipend program regarding enrollment of girls students

\begin{tabular}{ccccccc}
\hline Items & $\mathrm{A}$ & $\mathrm{SA}$ & $\mathrm{U}$ & $\mathrm{D}$ & $\mathrm{SA}$ & Total \\
\hline 1 & $67 \%$ & $19 \%$ & $9 \%$ & $3 \%$ & $2 \%$ & $100 \%$ \\
2 & $62 \%$ & $29 \%$ & $3 \%$ & $4 \%$ & $2 \%$ & $100 \%$ \\
3 & $53 \%$ & $22 \%$ & $16 \%$ & $8 \%$ & $1 \%$ & $100 \%$ \\
4 & $33 \%$ & $12 \%$ & $40 \%$ & $6 \%$ & $9 \%$ & $100 \%$ \\
Aggregate & $54 \%$ & $21 \%$ & $17 \%$ & $5 \%$ & $4 \%$ & $100 \%$ \\
percentage & & & & & & \\
\hline
\end{tabular}

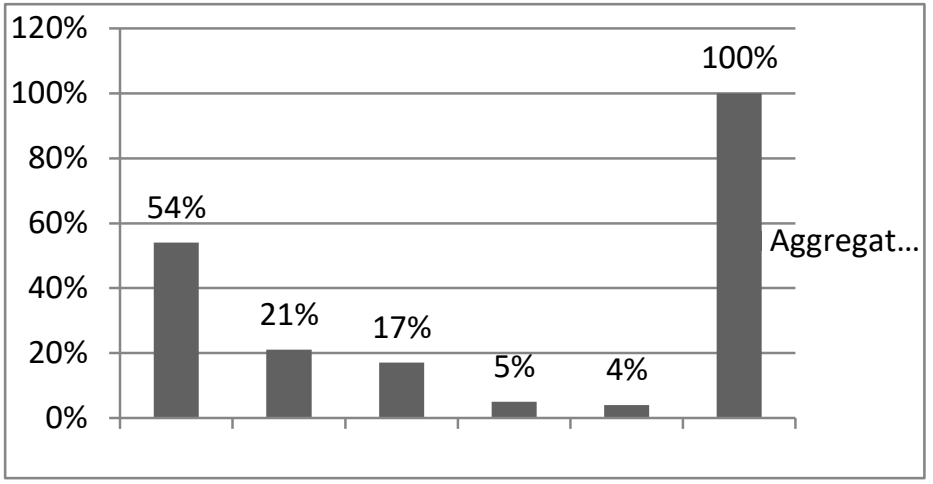

Table 4.2 Head teachers' satisfaction with the attendance of girls' student due to girls' stipend program

\begin{tabular}{ccccccc}
\hline Items & $\mathrm{A}$ & $\mathrm{SA}$ & $\mathrm{U}$ & $\mathrm{D}$ & $\mathrm{SA}$ & Total \\
\hline 5. & $68 \%$ & $27 \%$ & $0 \%$ & $5 \%$ & $0 \%$ & $100 \%$ \\
6. & $12 \%$ & $9 \%$ & $3 \%$ & $71 \%$ & $6 \%$ & $100 \%$ \\
7. & $61 \%$ & $25 \%$ & $5 \%$ & $3 \%$ & $5 \%$ & $100 \%$ \\
8. & $23 \%$ & $9 \%$ & $8 \%$ & $32 \%$ & $28 \%$ & $100 \%$ \\
Aggregate & $40 \%$ & $18 \%$ & $4 \%$ & $28 \%$ & $10 \%$ & $100 \%$ \\
percentage & & & & & & \\
\hline
\end{tabular}




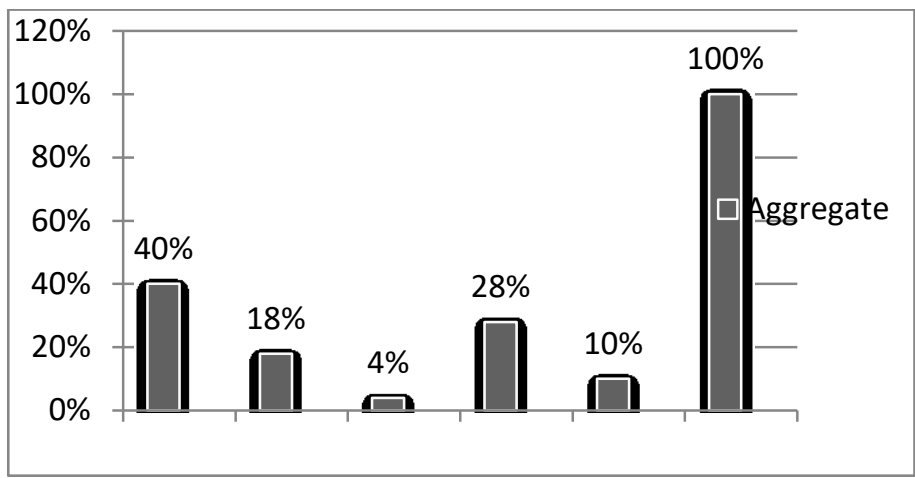

Analysis revealed that majority of head teachers satisfied about the attendance of girls' students due to girls' stipend program.

Table 4.3 Perceptions of head teachers about the interest level of girls' students increased after girls' stipend program

\begin{tabular}{ccccccc}
\hline Items & $\mathrm{A}$ & $\mathrm{SA}$ & $\mathrm{U}$ & $\mathrm{D}$ & $\mathrm{SA}$ & Total \\
\hline 9. & $66 \%$ & $26 \%$ & $2 \%$ & $7 \%$ & $0 \%$ & $100 \%$ \\
10. & $62 \%$ & $29 \%$ & $1 \%$ & $7 \%$ & $1 \%$ & $100 \%$ \\
11. & $63 \%$ & $16 \%$ & $6 \%$ & $15 \%$ & $1 \%$ & $100 \%$ \\
Aggregate & $67 \%$ & $24 \%$ & $3 \%$ & $5 \%$ & $1 \%$ & $100 \%$ \\
percentage & & & & & & \\
\hline
\end{tabular}

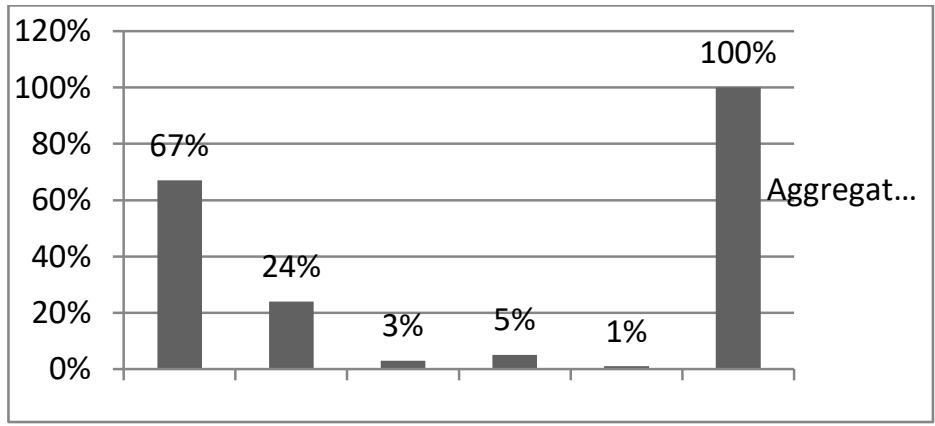

According the above given table majority of head teachers agreed with interest level of girls students increased after girls stipend program started. 
Table 4.4 Head teachers' perceptions about that encouragement of parents of girls' students due to girls' stipend program

\begin{tabular}{ccccccc}
\hline Items & $\mathrm{A}$ & $\mathrm{SA}$ & $\mathrm{U}$ & $\mathrm{D}$ & $\mathrm{SA}$ & Total \\
\hline 12. & $53 \%$ & $38 \%$ & $2 \%$ & $6 \%$ & $1 \%$ & $100 \%$ \\
13. & $34 \%$ & $26 \%$ & $5 \%$ & $26 \%$ & $9 \%$ & $100 \%$ \\
14. & $38 \%$ & $4 \%$ & $3 \%$ & $25 \%$ & $29 \%$ & $100 \%$ \\
Aggregate & $42 \%$ & $23 \%$ & $3 \%$ & $19 \%$ & $13 \%$ & $100 \%$ \\
percentage & & & & & & \\
\hline
\end{tabular}

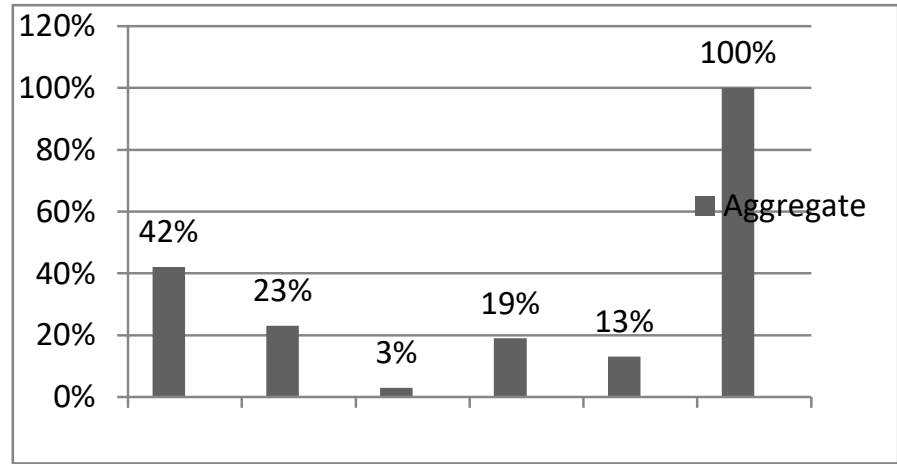

According table majority of participants agreed about encouragement of parents of girls students enhanced due to girls stipend program.

Table 4.5 Head teachers' perceptions about motivational level of girls and their parents due to Girls stipend program

\begin{tabular}{ccccccc}
\hline Items & $\mathrm{A}$ & $\mathrm{SA}$ & $\mathrm{U}$ & $\mathrm{D}$ & $\mathrm{SA}$ & Total \\
\hline 15. & $74 \%$ & $9 \%$ & $9 \%$ & $6 \%$ & $2 \%$ & $100 \%$ \\
16. & $56 \%$ & $26 \%$ & $6 \%$ & $10 \%$ & $2 \%$ & $100 \%$ \\
17. & $54 \%$ & $17 \%$ & $7 \%$ & $18 \%$ & $3 \%$ & $100 \%$ \\
18. & $30 \%$ & $13 \%$ & $32 \%$ & $19 \%$ & $6 \%$ & $100 \%$ \\
19. & $26 \%$ & $6 \%$ & $10 \%$ & $39 \%$ & $19 \%$ & $100 \%$ \\
20. & $55 \%$ & $12 \%$ & $9 \%$ & $12 \%$ & $11 \%$ & $100 \%$ \\
Aggregate & $49 \%$ & $14 \%$ & $12 \%$ & $18 \%$ & $7 \%$ & $100 \%$ \\
percentage & & & & & & \\
\hline
\end{tabular}




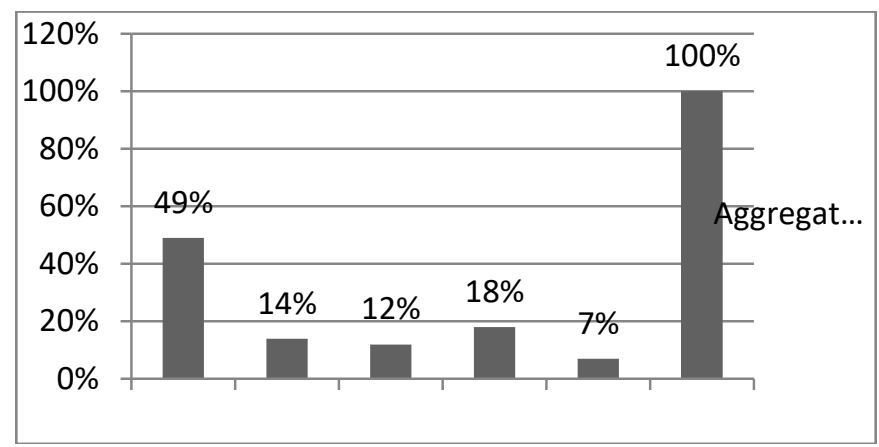

According the perception of head teachers majority of head teachers agreed regarding the motivational level of girls and their parents enhanced due to girls' stipend program.

Table 4.6 Head teachers' satisfaction on the continuity of girls' education in classes 6 to 10 due to the Girls stipend program

\begin{tabular}{ccccccc}
\hline Items & $\mathrm{A}$ & $\mathrm{SA}$ & $\mathrm{U}$ & $\mathrm{D}$ & $\mathrm{SA}$ & Total \\
\hline 21. & $65 \%$ & $12 \%$ & $5 \%$ & $18 \%$ & $0 \%$ & $100 \%$ \\
22. & $70 \%$ & $21 \%$ & $6 \%$ & $3 \%$ & $0 \%$ & $100 \%$ \\
23. & $42 \%$ & $41 \%$ & $10 \%$ & $4 \%$ & $3 \%$ & $100 \%$ \\
24. & $62 \%$ & $22 \%$ & $4 \%$ & $10 \%$ & $1 \%$ & $100 \%$ \\
25. & $68 \%$ & $13 \%$ & $9 \%$ & $6 \%$ & $4 \%$ & $100 \%$ \\
26. & $34 \%$ & $6 \%$ & $10 \%$ & $46 \%$ & $3 \%$ & $100 \%$ \\
Aggregate & $57 \%$ & $19 \%$ & $7 \%$ & $15 \%$ & $2 \%$ & $100 \%$ \\
percentage & & & & & & \\
\hline
\end{tabular}

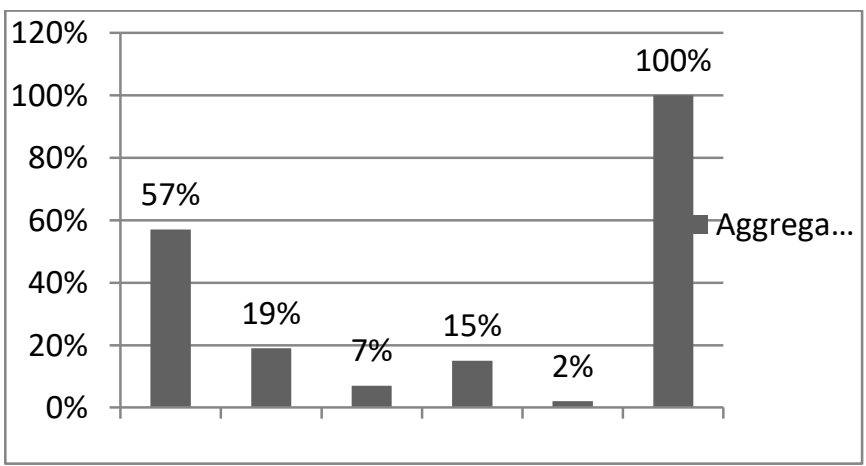


According the above given table majority of head teachers agreed with research question no: 6 , regarding the head teachers satisfaction of continuity of girls education in classes $6^{\text {th }}, 7^{\text {th }}, 8^{\text {th }}, 9^{\text {th }}$ and $10^{\text {th }}$ of public schools.

\section{Findings}

Results of this research showed that girl's stipend program became motivational factor for the girls' students to enroll themselves in the schools after completing primary education, $54 \%$ head teachers agreed that due to girls' stipend program enrolment of girls students increased after primary education and after 2001 enrollment of girls' students is increasing every year because of stipend program. Specially, poor girls depended upon stipend amount which is providing by Sindh government. As the Sindh government targeted to enhance the enrolment of girls students in $6^{\text {th }}$ to $10^{\text {th }}$ classes, that objective of improving the enrollment of girls students is achieving by the help of annually girls stipend program in all public schools of Sindh. Findings this study identified that girls of rural areas gave more importance to stipend amount than urban areas, so girl's stipend program attracted girls' students from the rural areas. Urban areas had more facilities and awareness about the education, so that girls of cities got admission without considering girls stipend program.

For Q. no $240 \%$ head teachers were agree with attendance of students. According the Head teachers' responses, findings of this study identified that absenteeism of girls students decreased due to the girls' stipend program, and attendance of girls students also remained above than $80 \%$ as per requirement of stipend program, but parents' involvement regarding the attendance of their daughters with Head Teachers was not satisfied.

According the Q.No: 3. 67\% Head teachers agreed that interest level of girls' students increased due to girls' stipend program, keeping in view analyzed data, it was found that girl's stipend program succeeded to increase the girls' interest level for secondary education, especially for those girls who belongs to poor families. After completing primary education, girls stipend program motivated the girls students to get admission in $6^{\text {th }}$ class and towards, in this way, every year girls admission increased in classes $6^{\text {th }}, 7^{\text {th }}, 8^{\text {th }}, 9^{\text {th }}$ and $10^{\text {th }}$.

According the perception of Head Teachers $42 \%$ HT agreed and 23 strongly agreed with the Q: no4. Findings of this study showed that parents/guardians of girls' students encouraged their daughters to continue their study after getting admission in class $6^{\text {th }}$ in public school. Regarding the transparency in stipend amount, parents/guardians were satisfied but due to the complexity in the disbursement process complains came during the disbursement time, Involvement of parents /guardians in educational matters increased due to girls stipend program. 
For the research Q:no 5 49\% HT agreed, Mostly Head Teachers pointed out that, all over girls' education improved because of girls' stipend program and stipend program put positive impact to enhance the enrolment of girls' students for secondary education and reduced gender disparity for girls in education the attainment in public schools. Majority of Head Teachers responded as disagree for amount of stipend, which was given by Sindh government to girls students, that amount could not complete basic needs of girls' students, but the awareness of importance of education increased in girls students as well as parents/guardians of girls students. For the research Q:no 6.57\% HT agreed and identified that girls stipend program decreased the drop out ration of girls students during the secondary education and made them regular ,punctual in their study.

\section{Discussion}

The results of the current study in the area of enrollment of girl students increased due to stipend program in secondary level education and are similar with Mahmud (2003), who had conducted same type of research in Bangladesh. Moreover, findings of study conducted by Doller and Gatti (1999) also reported the similar results about female education improved due to financial support. The results of the current study regarding attendance of girls students increased because of stipend program are in line with Sperling and Barbara (2004) who had conducted same type of research in New York.

\section{Conclusions}

Analyzed results concluded that girl's stipend program improved the enrollment of girls' students in secondary education in public school and attendance of students remained above than $80 \%$ as per requirement of girls' stipend program. Findings of this study showed that interest level and motivational level of girls' students and their parents enhanced due to the stipend program, encouragement of parents to leave their daughters for study also increased after girls stipend program started. Due to the stipend amount girls' students continued their study and mostly girls' students completed their secondary education, in this way; drop out ratio decreased from the secondary education for girls' students studying in class 6 th to $10^{\text {th }}$ in public schools. Finally it was concluded that girls' stipend program motivated girls' students and their parents to continue their studies, it maintained the transparency in disbursement of stipend amount. Girls students fulfilled their financial needs by annual stipend amount, in this way; dropout ratio decreased from secondary education. 


\section{Recommendations}

On the basis of findings of this research work, there are some suggestions to increase enrolment rate of girls' students from primary education to secondary education in public schools of Sindh

1. On need basis, Girls middle and high public schools should be increase in every union council of Sindh province, especially in rural areas and Girls stipend amount should be increased and provided stipend amount in the starting of the academic year

2. Competent teaching staff and non- teaching staff of girls' schools should be female and provide facilities of free pick and drop to all enrolled girls students in public schools, specially where there is no facilities of access.

3. Provide basic facilities in girls' public schools such as furniture, drinking water, electricity, and toilet and play ground.

4. Along with stipend amount government should support the poor girls' students with additional facilities like stationary, shoes, uniform and registers.

5. stipend amount should be increased and delivered to the girls students in starting of the year , and complains regarding the stipend amount should be solve immediately so that Head teachers and girls students do not face any disturbances in teaching and learning process.

6. Head teachers should arrange educational awareness programs for parents of girls' students, in which high authorities of education department should deliver motivational and fruitful speeches to encourage the communities for girls' education

7. Create more job opportunities for female so that after completing education they could serve the society.

\section{References}

Dollar, D., \& Gatti. R. (1999). Gender Inequality, Income, and Growth: Are Good Times Good For Women? Policy Research Report on Gender and Development, Working Paper Series 1, Washington, DC: World Bank.

Government of Pakistan (2008). Education for All: Mid Decade Assessment Country Report. Islamabad: Ministry of Education

Government of Pakistan (1947). Proceedings of the Pakistan Educational Conference. Islamabad, Ministry of the Interior (Education Division).

Hahn, Y., Islam, A., Patacchini, E., \& Zenou, Y. (2015). Teams, Organization and Education Outcomes. London: Centre for Economic Policy Research. 
Herz, B. (1991). Letting Girls Learn: Promising Approaches in Primary and Secondary Education. World Bank Discussion Papers, No. 133. Publication Sales Unit

Khandker, S., Pitt, M., \& Fuwa, N. (2003). Subsidy to Promote Girls' Secondary Education: The Female Stipend Program in Bangladesh, MPRA Paper, University Library of Munich, Germany.

Mahmud, S. (2003). Female secondary school stipend programme in Bangladesh. United Back ground paper prepared for the Education for All Global Monitoring Report, 4

RSU. (2018). Retrieved from http://www.rsu-sindh.gov.pk/units/girlsStipend.php

School Education and Literacy Department. (2018). Retrieved from http://www.sindheducation.gov.pk

Sen, A. (2000). Social Exclusion: Concept, Application and Scrutiny. Manila: Asian Development Bank, Office of Environment and Social Development.

Sindh Education Foundation. (2018). Retrieved from https://www.sef.org.pk

Sperling, G. B., \& Barbara, H. (2004). What Works in Girls' Education: Evidence and Politics from the Developing World. New York: Council on Foreign Relations.

United Nations. (2012). Millennium development goals gap task force report 2012. United Nations Pubns.

World Bank (2005). Donor Appraisal and Endorsement Report: National Strategy for Education Development of the Republic of Tajikistan. 